\title{
Exchange Rate Changes and Stock Returns: The Recent Cases of the Japanese Electric Appliances Industry Firms
}

\author{
Chikashi Tsuji (Corresponding author) \\ Graduate School of Systems and Information Engineering \\ University of Tsukuba \\ 1-1-1 Tennodai, Tsukuba, Ibaraki 305-8573, Japan \\ Tel: 81-29-853-2111 E-mail: mail_sec_low@minos.ocn.ne.jp
}

Received: September 7, 2012

Accepted: September 19, 2012

OnlinePublished: September 20, 2012

doi:10.5430/jbar.v1n2p71

URL: http://dx.doi.org/10.5430/jbar.v1n2p71

The research is financed by the Japan Society for the Promotion of Science and the author greatly acknowledges their generous financial assistance for this research.

\begin{abstract}
This study explores the time-series dynamics of the sensitivities of stock returns to the US-yen exchange rates. We also investigate whether the US-yen exchange rates are priced in recent periods in the Japanese electric appliances industry. Our investigations firstly indicate that recently, the sensitivities of the Japanese electric appliances industry stocks to exchange rates increased. Further, our standard regressions clearly show that as to the Japanese electric appliances industry firms, in the recent periods, exchange rate changes are priced in the Japanese equity markets.
\end{abstract}

Keywords: Asset pricing, Exchange rate sensitivity, Japanese electric appliances Industry

\section{Introduction}

Exchange rate changes are risks for investors and the relations between exchange rate dynamics and stock returns were often discussed. Related important studies were, for example, those by Francis et al. (2008), Bartov and Bodnar (1994), De Santis and Gerard (1998), Jorion (1990, 1991), Mun (2007, 2012), Shapiro (1975), and Verdelhan(2010). In the preceding studies, theoretical models derived by Ross (1976) or Merton (1973) were often used. Ross (1976) suggested APT (Arbitrage Pricing Theory) and Merton (1973) developed the ICAPM (Intertemporal Capital Asset Pricing Model).

In this paper, we particularly focus on the recent sample periods and the Japanese export-oriented industry since recently, the Japanese yen very much appreciated and this would negatively affect the profitability of the Japanese export industry firms. Therefore, the objectives in this paper are to empirically explore the stock return sensitivities to the US-yen exchange rate changes and statistically test the relations between exchange rate changes and stock returns of the Japanese electric appliances industry firms. Our main contribution is the following empirical finding. Namely, in this paper, we find that recently, with regard to the Japanese electric appliances industry firms, exchange rate changes are statistically significantly priced in stock markets.

The rest of this paper is as follows. First, Section 2 explains our data set and research design, Section 3 documents our empirical evidence, and Section 4 concludes the paper.

\section{Data and Research Design}

Our data used in our analyses are supplied by QUICK Corp., and the sample period is from January 1990 to June 2012. The notations of the variables we use in this paper are as follows. First, DEF denotes the default spreads (corporate bond index yields minus short-term interest rates), TERM is the term spreads (10-year government bond yields minus short-term interest rates), IP denotes the log base percentage changes of the seasonally adjusted industry productions, CPI is the CPI growth rates in percentage, MVOL denotes the historical market returns' volatilities, and $\triangle \mathrm{EX}$ means the changes of the yen/US dollars exchange rates. As to the above variables, DEF, TERM, and IP were used in the well-known study by Chen et al. (1986), and CPI and MVOL were used in Hong et al. (2007).

In addition, we computed the exchange rate sensitivities of two Japanese electric appliances industry's companies' 
stock returns. These time-series dynamics are displayed in Panels A to B in Figure 1. Explaining the companies' names, 'Hitachi' denotes Hitachi, Ltd., and 'NEC' is NEC Corporation. We use these two firms' data since they are famous Japanese electric appliances industry firms in the world.

To design our empirical researches, we divide our full sample period into five sub-periods. The first sub-period starts January 1990 and ends August 1994, the second sub-period starts September 1994 and ends April 1999, the third sub-period starts May 1999 and ends December 2003, the fourth one starts January 2004 and ends September 2008, and the latest sub-period starts October 2008 and ends June 2012. We note that our final sub-period is that after the US Lehman Shock. Further, monthly observations are 56, 56, 56, 57, and 46 in our five sub-periods in order, thus five sub-periods include almost equal samples. Then for two firms and for all five sub-periods, we perform seven kinds of regressions. The formula of our full regression is as follows, and this is our model 7 in Tables 1 to 5 .

$$
R E T_{i, t}=\kappa+\psi_{1} D E F_{t}+\psi_{2} T E R M_{t}+\psi_{3} I P_{t}+\psi_{4} C P I_{t}+\psi_{5} M V O L_{t}+\psi_{6} \Delta E X_{t}+\tau_{i, t} .
$$

Where $R E T_{i, t}$ denotes each company's stock return and as to other explanatory variables, we explained before. As shown in Tables 1 to 5, we perform models 1 to 7 by using the variables in our regression (1). We emphasize that our focus is on the statistical significance and signs of the coefficients of the variable, $\Delta \mathrm{EX}$, in recent sub-sample periods. The magnitudes of $R$-squared values are not so important.

\section{Empirical Evidence}

We show our empirical results in Tables 1 to 5. Panel A shows the results of 'Hitachi', and Panel B exhibits the results of 'NEC'. The results in these tables are the evidence from our seven kinds of regressions. Again, our focus in our analyses is on the statistical significance and the signs of the coefficients of the variable, $\Delta \mathrm{EX}$.

In short, in Tables 1 to 3, little statistical significance of $\Delta \mathrm{EX}$ is seen. On the other hand, in Tables 4 and 5 , both 'Hitachi' and 'NEC' exhibit the statistically significant positive coefficients in our models 6 and 7. These results mean that as to 'Hitachi' and 'NEC', which are in the Japanese electric appliances industry, US-yen exchange rate changes are statistically strongly priced in the Japanese stock markets with positive relations, especially in the recent periods of January 2004 to September 2008 and October 2008 to June 2012. The positive relations found in the recent sample periods mean the yen appreciations and stock return declines of these two companies in recent years.

\section{Conclusions}

This paper investigated the US-yen exchange rate sensitivities of two famous electric appliances industry firms in Japan. As far as we know, there seems to be no existing study that performed the empirical analyses like ours. Our significant contributions in this paper are as follows.

- First, we find that in recent sample periods, with regard to two Japanese export-oriented firms of 'Hitachi' and 'NEC', their US-yen exchange rate sensitivities clearly increased.

- Second, as to the Japanese electric appliances industry firms, our empirical tests demonstrated that the US-yen exchange rate dynamics are statistically strongly priced with positive signs in recent sample periods.

We consider that, in order to further deepen our knowledge with regard to the (in)efficient financial markets, related future researches around the world by using international data and in similar contexts shall be valuable. We also consider that the dynamics of the yen against other currencies than the USdollars in recent years may be one of the interesting research topics in the future.

\section{Acknowledgement}

The author greatly thanks the repeated kind paper invitations from the Editors of this Journal. I also thank the Editor and an anonymous referee for their kind comments to the first version of this paper.

\section{References}

Bartov, E., \& Bodnar, G. (1994). Firm valuation, earnings expectations, and the exchange rate effect. Journal of Finance. 49, 1755-1785. http://dx.doi.org/10.1111/j.1540-6261.1994.tb04780.x

Chen, N. F., Roll, R., \& Ross, S. A. (1986). Economic Forces and the Stock Market. The Journal of Business. 59, 383-403.

De Santis, G., \& Gerard, B. (1998). How big is the premium for currency risk? Journal of Financial Economics. 49, 375-412. http://dx.doi.org/10.1016/S0304-405X(98)00029-4

Francis, B., Hasan, I., \& Hunter, D. (2008). Can hedging tell the full story? Reconciling differences in United States aggregate-and industry-level exchange rate risk premium. Journal of Financial Economics. 90, 169-196. 
http://dx.doi.org/10.1016/j.jfineco.2007.10.007

Hong, H., Torous, W., \& Valkanov, R. (2007). Do industries lead stock markets? Journal of Financial Economics. 83, 367-396. http://dx.doi.org/10.1016/j.jfineco.2005.09.010

Jorion, P. (1990). The exchange-rate exposure of US multinationals. Journal of Business. 63, 331-346.

Jorion, P. (1991). The pricing of exchange rate risk in the stock market. Journal of Financial and Quantitative Analysis. 64, 363-376. http://dx.doi.org/10.2307/2331212

Merton, R. C. (1973). An Intertemporal Capital Asset Pricing Model. Econometrica. 41, 867-887.

Mun, K. C. (2007). Volatility and correlation in international stock markets and the role of exchange rate fluctuations. Journal of International Financial Markets, Institutions and Money. 17, 25-41. http://dx.doi.org/10.1016/j.intfin.2005.08.006

Mun, K. C. (2012). The joint response of stock and foreign exchange markets to macroeconomic surprises: Using US and Japanese data. Journal of Banking \& Finance. 36, 383-394. http://dx.doi.org/10.1016/j.jbankfin.2011.07.014

Newey, W. K., \& West, K. D. (1987). A simple, positive semi-definite, heteroskedasticity and autocorrelation consistent covariance matrix. Econometrica. 55, 703-708. http://dx.doi.org/10.2307/1913610

Ross, S. A. (1976). The arbitrage theory of capital asset pricing. Journal of Economic Theory.13, 341-360. http://dx.doi.org/10.1016/0022-0531(76)90046-6

Shapiro, A. C. (1975). Exchange rate changes, inflation, and the value of the multinational corporation. Journal of Finance. 30, 485-502. http://dx.doi.org/10.1111/j.1540-6261.1975.tb01824.x

Verdelhan, A. (2010). A Habit-Based Explanation of the Exchange Rate Risk Premium. Journal of Finance. 65, 123-146. http://dx.doi.org/10.1111/j.1540-6261.2009.01525.x 
Table 1. The Results of Regressions on the Cases of Hitachi and NEC: January 1990 to August 1994

\begin{tabular}{|c|c|c|c|c|c|c|c|}
\hline \multicolumn{8}{|c|}{ Panel A. Hitachi } \\
\hline & Model 1 & Model 2 & Model 3 & Model 4 & Model 5 & Model 6 & Model 7 \\
\hline Constant & -0.761 & -0.426 & -0.337 & 1.186 & -1.840 & -0.084 & 5.600 \\
\hline$p$-value & 0.467 & 0.644 & 0.710 & 0.488 & 0.788 & 0.917 & 0.578 \\
\hline DEF & 0.780 & & & & & & 4.813 \\
\hline$p$-value & 0.237 & & & & & & 0.146 \\
\hline TERM & & 0.696 & & & & & -3.932 \\
\hline$p$-value & & 0.421 & & & & & 0.334 \\
\hline IP & & & -0.789 & & & & -0.697 \\
\hline$p$-value & & & 0.343 & & & & 0.467 \\
\hline CPI & & & & -0.707 & & & 1.155 \\
\hline$p$-value & & & & 0.368 & & & 0.472 \\
\hline MVOL & & & & & 0.054 & & -0.361 \\
\hline$p$-value & & & & & 0.815 & & 0.286 \\
\hline$\Delta \mathrm{EX}$ & & & & & & 0.274 & 0.161 \\
\hline$p$-value & & & & & & 0.391 & 0.654 \\
\hline $\operatorname{Adj} . R^{2}$ & 0.001 & -0.009 & 0.007 & -0.008 & -0.018 & -0.004 & -0.043 \\
\hline \multicolumn{8}{|c|}{ Panel B. NEC } \\
\hline & Model 1 & Model 2 & Model 3 & Model 4 & Model 5 & Model 6 & Model 7 \\
\hline Constant & -0.665 & -0.259 & -0.190 & 2.128 & -2.589 & 0.157 & 8.976 \\
\hline$p$-value & 0.677 & 0.865 & 0.899 & 0.465 & 0.800 & 0.903 & 0.567 \\
\hline DEF & 0.935 & & & & & & 4.553 \\
\hline$p$-value & 0.276 & & & & & & 0.363 \\
\hline TERM & & 0.805 & & & & & -4.022 \\
\hline$p$-value & & 0.468 & & & & & 0.540 \\
\hline IP & & & -1.613 & & & & -1.517 \\
\hline$p$-value & & & 0.247 & & & & 0.334 \\
\hline $\mathrm{CPI}$ & & & & -1.067 & & & 0.456 \\
\hline$p$-value & & & & 0.361 & & & 0.854 \\
\hline MVOL & & & & & 0.086 & & -0.416 \\
\hline$p$-value & & & & & 0.809 & & 0.395 \\
\hline$\Delta \mathrm{EX}$ & & & & & & 0.342 & 0.167 \\
\hline$p$-value & & & & & & 0.502 & 0.775 \\
\hline Adj. $R^{2}$ & -0.006 & -0.012 & 0.032 & -0.007 & -0.018 & -0.008 & -0.039 \\
\hline
\end{tabular}

Notes: 'Hitachi' denotes Hitachi, Ltd., and 'NEC' denotes NEC Corporation. Further, Adj. $R^{2}$ denotes the adjusted $R$-squared values. ${ }^{* *},{ }^{* *}$, and $*$ denote the statistical significance at the $1 \%, 5 \%$, and $10 \%$ level, respectively. Moreover, we use the method of Newey-West (1987), thus $p$-values are robust to the heteroskedasticity and autocorrelation of the error terms of regressions. 
Table 2. The Results of Regressions on the Cases of Hitachi and NEC: September 1994 to April 1999

\begin{tabular}{|c|c|c|c|c|c|c|c|}
\hline \multicolumn{8}{|c|}{ Panel A. Hitachi } \\
\hline & Model 1 & Model 2 & Model 3 & Model 4 & Model 5 & Model 6 & Model 7 \\
\hline Constant & -8.280 & -2.848 & 0.267 & 0.472 & -5.400 & 0.196 & -40.619 \\
\hline$p$-value & 0.256 & 0.481 & 0.805 & 0.729 & 0.629 & 0.860 & 0.230 \\
\hline DEF & 3.479 & & & & & & 16.647 \\
\hline$p$-value & 0.212 & & & & & & 0.219 \\
\hline TERM & & 1.710 & & & & & -11.095 \\
\hline$p$-value & & 0.376 & & & & & 0.235 \\
\hline IP & & & $1.908 * *$ & & & & $2.192 * * *$ \\
\hline$p$-value & & & 0.011 & & & & 0.005 \\
\hline CPI & & & & -0.457 & & & 2.091 \\
\hline$p$-value & & & & 0.748 & & & 0.316 \\
\hline MVOL & & & & & 0.257 & & 0.863 \\
\hline$p$-value & & & & & 0.596 & & 0.305 \\
\hline$\Delta \mathrm{EX}$ & & & & & & 0.054 & 0.253 \\
\hline$p$-value & & & & & & 0.840 & 0.311 \\
\hline Adj. $R^{2}$ & 0.011 & -0.001 & 0.062 & -0.016 & -0.012 & -0.018 & 0.022 \\
\hline \multicolumn{8}{|c|}{ Panel B. NEC } \\
\hline & Model 1 & Model 2 & Model 3 & Model 4 & Model 5 & Model 6 & Model 7 \\
\hline Constant & -6.284 & -1.585 & 0.821 & 0.998 & -2.489 & 0.649 & -36.529 \\
\hline$p$-value & 0.400 & 0.710 & 0.530 & 0.571 & 0.848 & 0.608 & 0.264 \\
\hline DEF & 2.892 & & & & & & 15.619 \\
\hline$p$-value & 0.330 & & & & & & 0.244 \\
\hline TERM & & 1.319 & & & & & -11.189 \\
\hline$p$-value & & 0.547 & & & & & 0.244 \\
\hline IP & & & $1.612 *$ & & & & $2.265 * *$ \\
\hline$p$-value & & & 0.067 & & & & 0.017 \\
\hline CPI & & & & -0.392 & & & 1.869 \\
\hline$p$-value & & & & 0.762 & & & 0.390 \\
\hline MVOL & & & & & 0.150 & & 0.825 \\
\hline$p$-value & & & & & 0.799 & & 0.350 \\
\hline$\Delta \mathrm{EX}$ & & & & & & 0.364 & $0.588^{*}$ \\
\hline$p$-value & & & & & & 0.201 & 0.063 \\
\hline Adj. $R^{2}$ & -0.001 & -0.010 & 0.031 & -0.017 & -0.017 & 0.005 & 0.018 \\
\hline
\end{tabular}

Notes: 'Hitachi' denotes Hitachi, Ltd., and 'NEC' denotes NEC Corporation. Further, Adj. $R^{2}$ denotes the adjusted $R$-squared values. ${ }^{* *},{ }^{* *}$, and $*$ denote the statistical significance at the $1 \%, 5 \%$, and $10 \%$ level, respectively. Moreover, we use the method of Newey-West (1987), thus $p$-values are robust to the heteroskedasticity and autocorrelation of the error terms of regressions. 
Table 3. The Results of Regressions on the Cases of Hitachi and NEC: May 1999 to December 2003

\begin{tabular}{|c|c|c|c|c|c|c|c|}
\hline \multicolumn{8}{|c|}{ Panel A. Hitachi } \\
\hline & Model 1 & Model 2 & Model 3 & Model 4 & Model 5 & Model 6 & Model 7 \\
\hline Constant & -4.999 & -4.537 & 0.085 & 0.848 & -7.566 & 0.025 & 5.973 \\
\hline$p$-value & 0.443 & 0.485 & 0.956 & 0.734 & 0.744 & 0.987 & 0.851 \\
\hline DEF & 3.094 & & & & & & 10.272 \\
\hline$p$-value & 0.408 & & & & & & 0.472 \\
\hline TERM & & 3.458 & & & & & -7.800 \\
\hline$p$-value & & 0.461 & & & & & 0.638 \\
\hline IP & & & 0.032 & & & & -0.547 \\
\hline$p$-value & & & 0.973 & & & & 0.665 \\
\hline CPI & & & & 1.224 & & & 0.310 \\
\hline$p$-value & & & & 0.741 & & & 0.951 \\
\hline MVOL & & & & & 0.367 & & -0.584 \\
\hline$p$-value & & & & & 0.739 & & 0.749 \\
\hline$\Delta \mathrm{EX}$ & & & & & & -0.296 & -0.269 \\
\hline$p$-value & & & & & & 0.545 & 0.687 \\
\hline Adj. $R^{2}$ & -0.002 & -0.007 & -0.019 & -0.017 & -0.016 & -0.012 & -0.089 \\
\hline \multicolumn{8}{|c|}{ Panel B. NEC } \\
\hline & Model 1 & Model 2 & Model 3 & Model 4 & Model 5 & Model 6 & Model 7 \\
\hline Constant & -3.506 & -2.872 & -0.115 & $7.480 * *$ & -0.102 & -0.104 & -17.230 \\
\hline$p$-value & 0.760 & 0.807 & 0.957 & 0.032 & 0.998 & 0.961 & 0.622 \\
\hline DEF & 2.126 & & & & & & -5.678 \\
\hline$p$-value & 0.734 & & & & & & 0.713 \\
\hline TERM & & 2.140 & & & & & 8.620 \\
\hline$p$-value & & 0.788 & & & & & 0.616 \\
\hline IP & & & 1.329 & & & & 1.583 \\
\hline$p$-value & & & 0.402 & & & & 0.357 \\
\hline CPI & & & & $12.062 * * *$ & & & $14.642 * * *$ \\
\hline$p$-value & & & & 0.008 & & & 0.003 \\
\hline MVOL & & & & & 0.004 & & 1.157 \\
\hline$p$-value & & & & & 0.998 & & 0.562 \\
\hline$\Delta \mathrm{EX}$ & & & & & & -0.445 & 0.404 \\
\hline$p$-value & & & & & & 0.549 & 0.629 \\
\hline Adj. $R^{2}$ & -0.014 & -0.016 & -0.001 & 0.086 & -0.019 & -0.010 & 0.030 \\
\hline
\end{tabular}

Notes: 'Hitachi' denotes Hitachi, Ltd., and 'NEC' denotes NEC Corporation. Further, Adj. $R^{2}$ denotes the adjusted $R$-squared values. ${ }^{* *},{ }^{* *}$, and $*$ denote the statistical significance at the $1 \%, 5 \%$, and $10 \%$ level, respectively. Moreover, we use the method of Newey-West (1987), thus $p$-values are robust to the heteroskedasticity and autocorrelation of the error terms of regressions. 
Table 4. The Results of Regressions on the Cases of Hitachi and NEC: January 2004 to September 2008

\begin{tabular}{|c|c|c|c|c|c|c|c|}
\hline \multicolumn{8}{|c|}{ Panel A. Hitachi } \\
\hline & Model 1 & Model 2 & Model 3 & Model 4 & Model 5 & Model 6 & Model 7 \\
\hline Constant & -1.312 & -0.702 & 0.566 & 0.837 & -2.206 & 0.537 & -9.976 \\
\hline$p$-value & 0.868 & 0.899 & 0.510 & 0.346 & 0.819 & 0.494 & 0.538 \\
\hline DEF & 1.191 & & & & & & 20.631 \\
\hline$p$-value & 0.814 & & & & & & 0.274 \\
\hline TERM & & 0.921 & & & & & -21.634 \\
\hline$p$-value & & 0.821 & & & & & 0.224 \\
\hline IP & & & -0.410 & & & & -0.578 \\
\hline$p$-value & & & 0.631 & & & & 0.381 \\
\hline CPI & & & & -1.349 & & & $-3.578 *$ \\
\hline$p$-value & & & & 0.299 & & & 0.094 \\
\hline MVOL & & & & & 0.162 & & 0.501 \\
\hline$p$-value & & & & & 0.777 & & 0.495 \\
\hline$\Delta \mathrm{EX}$ & & & & & & $1.128 * *$ & $1.029 * *$ \\
\hline$p$-value & & & & & & 0.017 & 0.028 \\
\hline Adj. $R^{2}$ & -0.016 & -0.017 & -0.014 & 0.001 & -0.016 & 0.158 & 0.123 \\
\hline \multicolumn{8}{|c|}{ Panel B. NEC } \\
\hline & Model 1 & Model 2 & Model 3 & Model 4 & Model 5 & Model 6 & Model 7 \\
\hline Constant & -4.066 & -2.418 & -0.643 & 0.043 & -0.479 & -0.480 & -20.556 \\
\hline$p$-value & 0.600 & 0.689 & 0.571 & 0.968 & 0.970 & 0.654 & 0.371 \\
\hline DEF & 2.322 & & & & & & 40.834 \\
\hline$p$-value & 0.655 & & & & & & 0.230 \\
\hline TERM & & 1.448 & & & & & -42.321 \\
\hline$p$-value & & 0.748 & & & & & 0.205 \\
\hline IP & & & 1.087 & & & & 0.856 \\
\hline$p$-value & & & 0.343 & & & & 0.404 \\
\hline CPI & & & & -2.292 & & & $-5.971^{*}$ \\
\hline$p$-value & & & & 0.275 & & & 0.051 \\
\hline MVOL & & & & & -0.002 & & 0.877 \\
\hline$p$-value & & & & & 0.998 & & 0.377 \\
\hline$\Delta \mathrm{EX}$ & & & & & & $1.227 * *$ & $1.104^{* *}$ \\
\hline$p$-value & & & & & & 0.014 & 0.013 \\
\hline Adj. $R^{2}$ & -0.014 & -0.016 & -0.001 & 0.011 & -0.018 & 0.091 & 0.097 \\
\hline
\end{tabular}

Notes: 'Hitachi' denotes Hitachi, Ltd., and 'NEC' denotes NEC Corporation. Further, Adj. $R^{2}$ denotes the adjusted $R$-squared values. ${ }^{* *}, * *$, and $*$ denote the statistical significance at the $1 \%, 5 \%$, and $10 \%$ level, respectively. Moreover, we use the method of Newey-West (1987), thus $p$-values are robust to the heteroskedasticity and autocorrelation of the error terms of regressions. 
Table 5. The Results of Regressions on the Cases of Hitachi and NEC: October 2008 to June 2012

\begin{tabular}{|c|c|c|c|c|c|c|c|}
\hline \multicolumn{8}{|c|}{ Panel A. Hitachi } \\
\hline & Model 1 & Model 2 & Model 3 & Model 4 & Model 5 & Model 6 & Model 7 \\
\hline Constant & 2.350 & -7.224 & 0.413 & -1.517 & -15.646 & 2.162 & 22.187 \\
\hline$p$-value & 0.847 & 0.421 & 0.776 & 0.601 & 0.484 & 0.165 & 0.319 \\
\hline DEF & -1.628 & & & & & & $-54.046^{*}$ \\
\hline$p$-value & 0.862 & & & & & & 0.081 \\
\hline TERM & & 6.794 & & & & & 55.560 \\
\hline$p$-value & & 0.427 & & & & & 0.153 \\
\hline IP & & & $1.426^{* * *}$ & & & & $0.887 * * *$ \\
\hline$p$-value & & & 0.001 & & & & 0.004 \\
\hline CPI & & & & -3.011 & & & 0.691 \\
\hline$p$-value & & & & 0.344 & & & 0.699 \\
\hline MVOL & & & & & 0.629 & & -0.122 \\
\hline$p$-value & & & & & 0.459 & & 0.877 \\
\hline$\Delta \mathrm{EX}$ & & & & & & $3.451 * * *$ & $3.166^{* * *}$ \\
\hline$p$-value & & & & & & 0.000 & 0.000 \\
\hline Adj. $R^{2}$ & -0.023 & -0.016 & 0.206 & 0.019 & -0.007 & -0.018 & 0.444 \\
\hline \multicolumn{8}{|c|}{ Panel B. NEC } \\
\hline & Model 1 & Model 2 & Model 3 & Model 4 & Model 5 & Model 6 & Model 7 \\
\hline Constant & -16.604 & -14.354 & -1.768 & -2.612 & -16.205 & -0.534 & -59.346 \\
\hline$p$-value & 0.282 & 0.218 & 0.281 & 0.274 & 0.367 & 0.690 & 0.114 \\
\hline DEF & 10.344 & & & & & & 52.551 \\
\hline$p$-value & 0.370 & & & & & & 0.304 \\
\hline TERM & & 11.492 & & & & & -51.635 \\
\hline$p$-value & & 0.325 & & & & & 0.407 \\
\hline IP & & & $1.077 * * *$ & & & & $1.118 * * *$ \\
\hline$p$-value & & & 0.001 & & & & 0.001 \\
\hline CPI & & & & -1.099 & & & 1.816 \\
\hline$p$-value & & & & 0.693 & & & 0.439 \\
\hline MVOL & & & & & 0.567 & & 1.646 \\
\hline$p$-value & & & & & 0.415 & & 0.181 \\
\hline$\Delta \mathrm{EX}$ & & & & & & $2.465 * * *$ & $2.064 * *$ \\
\hline$p$-value & & & & & & 0.002 & 0.022 \\
\hline Adj. $R^{2}$ & 0.001 & 0.003 & 0.133 & -0.016 & -0.008 & 0.190 & 0.273 \\
\hline
\end{tabular}

Notes: 'Hitachi' denotes Hitachi, Ltd., and 'NEC' denotes NEC Corporation. Further, Adj. $R^{2}$ denotes the adjusted $R$-squared values. ${ }^{* *}, * *$, and $*$ denote the statistical significance at the $1 \%, 5 \%$, and $10 \%$ level, respectively. Moreover, we use the method of Newey-West (1987), thus $p$-values are robust to the heteroskedasticity and autocorrelation of the error terms of regressions. 
Panel A. Hitachi

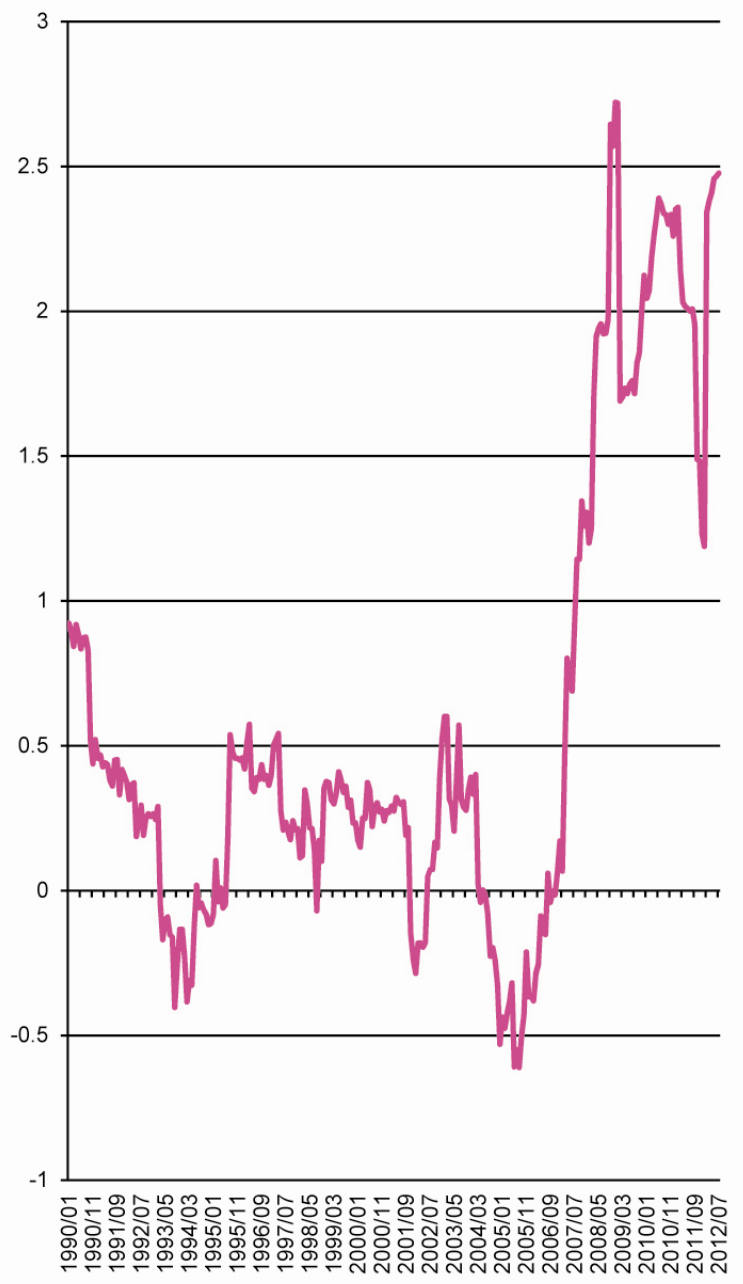

Panel B. NEC

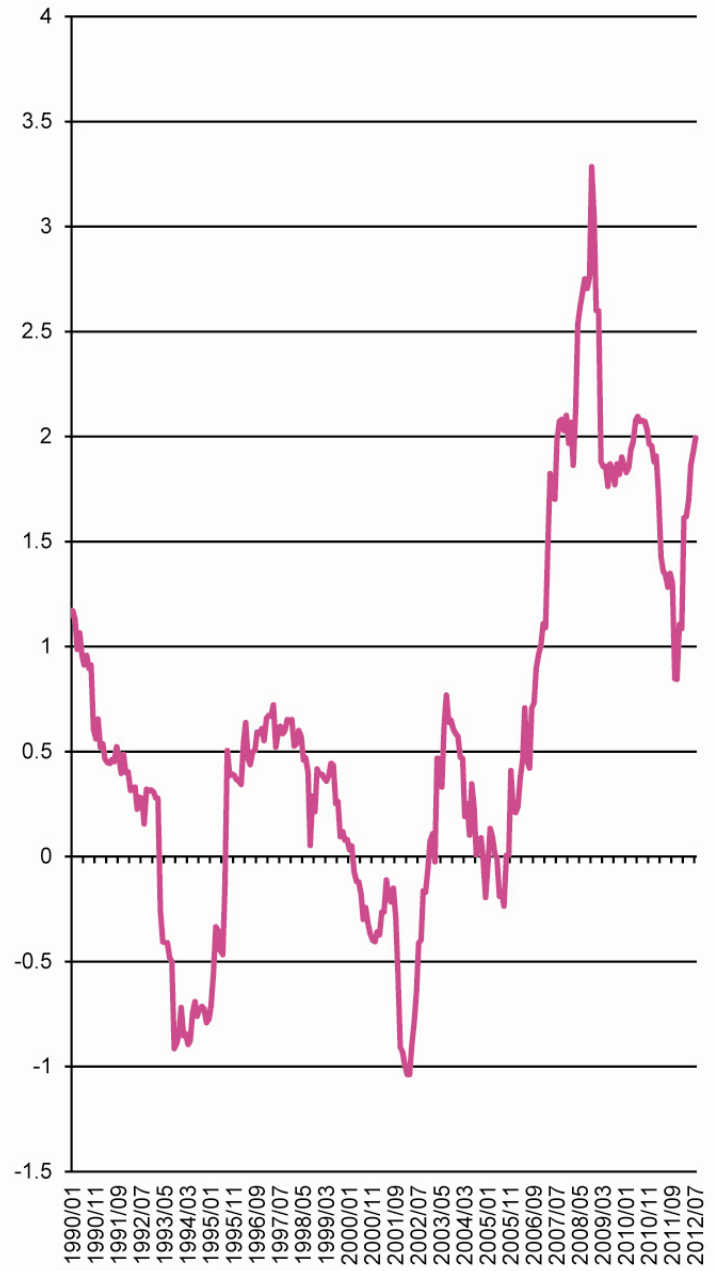

Figure 1. The Sensitivities of Stock Returns to Exchange Rates:

The Cases of the Japanese Electric Appliances Industry Firms 